\title{
Strategi dan Metode Dakwah Walisongo
}

Oleh: Hatmansyah, S.Ag., ME

\begin{abstract}
Walisongo believed to be laying the first stone of Islam in Java. Gait Walisongo the map Da'wah of Islam in Indonesia in general and on the island of Java in particular is indeed an indisputable historical fact.

The success da'wah $W$ alisongo is inseparable from the role srtategi and the methods they employ. The strategy that is First Division Da'wah Region. The Walisongo in preaching activities, among others, is taking into account the strategic region. Second, the system of Da'wah carried out with the introduction of Islam through persuasion oriented penaman Islamic faith yan adapted to the situation and conditions. Third, is to conduct an ideological war to eradicate the ethos and values of dogmatic ang contrary to the Islamic faith, in which the scholars have to create myths and new counter values are incompatible with Islam. Fourth, is to approach the figures that are deemed to bave influence somewhere and trying to avoid conflict. Fifth, trying mengguasai basic needs that are needed by the community, both the needs that are materially and spiritually.
\end{abstract}

Keywords: Walisongo, Strategies and Methods Da'wah

\section{A. Pendahuluan}

Sejarah mencatat peran besar para ulama' dalam mengemban dakwah di pelosok dunia termasuk di Indonesia sehingga Islam menjadi agama mayoritas di negeri ini. Salah satu topik menarik mengupas peran ulama dalam "islamisasi" di Indonesia adalah tindak tanduk dakwah para "Walisongo" di Pulau Jawa, mereka itu adalah Sunan Maulana Malik Ibrahim, Sunan Ampel, Sunan Giri, Sunan Gungung Jati, Sunan Muria, Sunan Kudus, Sunan Drajat, Sunan Kali Jaga, dan Sunan Bonang.

Walisongo dipercaya sebagai peletak batu pertama Islam di pulau Jawa. Kiprah Walisongo dalam peta dakwah Islam di Indonesia pada umumnya dan di pulau Jawa khususnya memang merupakan fakta sejarah yang tidak terbantahkan. Oleh sebab itu, wajar jika H.J. Vanden Berg pun tanpa ada rasa keraguan mengatakan, "Adapun yang memimpin penyebaran
Islam ini adalah para Wali, merekalah yang memimpin pengembangan agama Islam di seluruh Jawa" (Van Den Berg, 1959: 393).

Walisongo masyhur sebagai juru syiar kebenaran dan pekerja giat dalam menggembleng masyarakat, lahir-batin, di semua lapisan sosial, dari kelas "akar rumput" hingga ke para punggawa dan pembesar negeri. $\mathrm{Di}$ samping tetap memelihara sebagaimana dengan ajaran Islam murni, juga tidak tanggung-tanggung memberantas kebiasaan dan kepercayaan yang berbau kemusyrikan, lalu digiringnya kembali ke tauhid sejati.

Sejarah kesuksesan dakwah para Walisongo tersebut tentu tidak terlepas dari strategi dan metode dakwah yang dipergunakan dalam aktivitas dakwah. Selain strategi mereka juga mampu merumuskan garis- garis besar perjuangan dakwah yang harus dilaksakan secara taktis, mereka juga dibekali kemampuan teknis metode dakwah di lapangan. Perpaduan 
sinergis antara strategi dan metode dakwah inilah yang kemudian membawa hasil sehingga dakwah para Walisongo mendapat pujian baik di zamannya hingga saat ini.

\section{B. Walisongo Dan Aktivitas Dakwahnya}

\section{a. Pengertian Walisongo}

Secara etimologis istilah Walisongo berasal dari dua akar kata "wali' dan 'songo". Kata wali itu sendiri berasal dari bahasa Arab yang artinya "dekat" atau "kerabat", atau “teman” (Luis Ma'luf, 1061).

Kata "wali" menurut istilah, ialah sebutan bagi orang-orang Islam yang dianggap keramat, penyebar agama Islam, mereka dianggap "kekasih Allah", orangorang yang dekat dengan Allah, dikaruniai tenaga gaib, mempunyai kekuatan-kekuatan batin yang sangat berlebih, mempunyai ilmu yang sangat tinggi, dan sakti berjayakewijayaan (Effendy Zarkasi, 1977: 52).

Kata yang mendapat perhatian cukup intens dari istilah Walisongo adalah kata "Songo" itu sendiri. Ada yang berasumsi bahwa kata songo juga berasal dari bahasa kata Arab, yakni "tsana" yang maknanya sama dengan kata "mahmud", artinya terpuji atau mulia (Damani, 2001: 40). Sebagain lain ada mengatakan 'sana' berarti tempat, daerah atau wilayah. Sementara yang lain ada yang mengatakan, "songo" berasal dari bahasa Jawa yang artinya menunjuk pada bilangan sembilan, yakni beberapa wali yang terkenal itu dengan jumlah sembilan orang. Ada pun nama-nama sembilan orang Walisongo yang umumnua dikenal adalah Sunan Maulana Malik Ibrahim atau Sunan Gresik (wafat Tahun 1419), Sunan Ampel (lahir tahun 1401), Sunan Giri atau dikenal pula sebagai Raden Paku, Sunan Gungung Jati atau Syarif Hidayatullah atau juga dikenal dengan Fatahillah (wafat tahun 1570), Suan Muria atau Raden Said, Sunan Kudus atau dikenal pula sebagai Syekh Ja'far Shadiq, Sunan Drajat atau Raden Qasim, Sunan Kali Jaga yang juga digelari sebagai Raden Mas Syahid, Sunan Bonang atau Raden Ibrahim (1449-1525) (Arsyad, 1993: 132136). Tentang bilangan sembilan ini, sebagaimana dikutip oleh Effendy Zarkasi dari pendapat Prof. Dr. Tjan Tjoe Siem, bahwa bilangan sembilan itu memang merupakan simbol bagi orang Jawa yang berasal dari pengertian 8 (delapan) penjuru angin ditambah dengan pusat (tengah) (Effendy Zarkasi, 1977: 53).

\section{b. Aktivitas Dakwah Walisongo}

Walisongo dipercaya sebagai peletak batu pertama Islam di pulau Jawa. Kiprah Walisongo dalam peta dakwah Islam di Indonesia pada umumnya, di pulau Jawa khususnya memang merupakan fakta sejarah yang tidak terbantahkan. Oleh sebab itulah, wajar jika H.J. Vanden Berg pun tanpa ada rasa keraguan mengatakan, "Adapun yang memimpin penyebaran Islam ini adalah para Wali, merekalah yang memimpin pengembangan agama Islam di seluruh Jawa" (Van Den Berg, 1959: 393).

Walisongo masyhur sebagai juru syiar kebenaran dan pekerja giat dalam menggembleng masyarakat, lahir-batin, di semua lapisan sosial, dari kelas "akar rumput" hingga ke para punggawa dan pembesar negeri. Di samping tetap memelihara yang sudah sesuai dengan ajaran Islam murni, juga tidak tanggungtanggung memberantas kebiasaan dan 
kepercayaan yang berbau kemusyrikan, lalu digiringnya kembali ke tauhid sejati.

Seperti yang pernah dikemukakan oleh M. Natsir Arsyad dalam bukunya yang berjudul Seputar Sejarab \& Muamalah, paling tidak ada lima prinsip utama yang merupakan titik berat kiprah dakwah para Walisongo yang dijadikan patokan sembari menggodok kader:

1) Memelihara keyakinan beragama dengan membentanginya dari sekalian unsur yang bakal mencemari, apalagi merontokkannya.

2) Menjaga keselamatan harta, nyawa dan jiwa (rub) umat dari aneka ragam ancaman, seperti misalnya perampasan hak, pengibulan, frustrasi, bunuh diri, dan lain-lain.

3) Menanamkan pemahaman tentang berbagai hukum: pergaulan sosial, pernikahan, kesehatan, kebersihan, ilmu pengetahuan, demi menjaga anak keturunan, kesehatan jasad dan ruh, akhlak luhur, kecerdasan dan akal waras umat.

4) Melindungi akal pikiran sehat rakyat dari segala yang bisa menumpulkan dan merendahkannya, seperti menenggak minuman keras, malas belajar dan bekerja, dan mo-limo lainnya (Arsyad, 1993: 130).

5) Membendung atau menepis pengaruhpengaruh luar yang dapat memerosotkan kehormatan dan martabat nilai-nilai sosial, kemanusiaan dan agama.

\section{Stretegi Dan Metode Dakwah Walisongo}

a. Strategi Dakwah Walisongo

Strategi dapat diartikan sebagai tata cara dan usaha-usaha untuk menguasaidan mendayagunakan segala sumber daya untuk mencapai tujuan (Ali Motofo, 1971: 7). Dengan demikian, strategi dakwah yang dilakukan oleh Walisongo itu bisa diartikan menjadi segala cara yang ditempuh oleh para wali untuk mengajak manusia ke jalan Allah dengan memanfaatkan segala sumber daya yang dimiliki. Beberapa strategi Walisongo dalam pelaksanaan dakwah dapat dikemukakan antara lain sebagai berikut:

Pertama, Pembagian Wilayah Dakwah. Para Walisongo dalam melakukan aktivitas dakwahnya antara lain sangat memperhitungkan wilayah strategis. Beranjak dari sinilah, para Walisongo yang dikenal jumlahnya ada sembilan orang tersebut melakukan pemilihan wilayah dakwahnya tidak sembarangan. Penentuan tempat dakwahnya dipertimbangkan pula dengan faktor geostrategi yang sesuai dengan kondisi zamannya.

Kalau kita perhatikan dari kesembilan wali dalam pembagian wilayah kerjanya ternyata mempunyai dasar pertimbangan geostrategis yang mapan sekali. Kesembilan wali tersebut membagi kerja dengan rasio 5:3:1 (Suryanegara, 1995: 104). Jawa Timur mendapat perhatian besar dari para Walisongo. Di sini terdapat 5 Wali, dengan pembagian teritorial dakwah yang berbeda. Maulana Malik Ibrahim, sebagai wali perintis, mengambil wilayah dakwahnya di Gresik. Setelah Malik Ibrahim wafat, wilayah ini dikuasai oleh Sunan Giri. Sunan Ampel mengambil posisi dakwah wilayahnya di Surabaya, Sunan Bonang sedikit ke Utara di Tuban. Sedangkan Sunan Drajat di Sedayu. Berkumpulnya kelima wali ini di Jawa Timur adalah karena kekuasaan politik saat 
itu berpusat di wilayah ini. Kerajaan Kediri, di Kediri dan Majapahit di Mojokerto.

Di Jawa Tengah para wali mengambil posisi di Demak, Kudus, dan Muria. Sasaran dakwah para wali yang ada di Jawa Tengah tentu berbeda dengan yang ada di Jawa Timur. Di Jawa Tengah dapat dikatakan bahwa pusat kekuasaan politik Hindu dan Budha sudah tidak berperan lagi. Hanya para wali melihat realiatas masyarakat yang masih dipengaruhi oleh budaya yang bersumber dari ajaran Hidu dan Budha. Saat itu para Wali mengakui seni sebagai media komunikasi yang mempunyai pengaruh besar terhadap polapikir masyarakat. Oleh kerana itu, seni dan budaya yang sudah berakar di tengahtengah masyarakat menurut mereka perlu dimodifikasi, dan akhirnya bisa dimanfaatkan untuk kepentingan dakwah. Terakhir yaitu di Jawa Barat, menempatkan seorang wali yaitu Sunan Gunung Jati.

Kedua, sistem dakwah dilakukan dengan pengenalan ajaran Islam melalui pendekatan persuasif yang berorientasi pada penaman aqidah Islam yan disesuaikan dengan situasi dan kondisi yang ada. Rangkaian penggunaan sistem dakwah ini, misalnya kita dapati ketika Raden Rahmat atau Sunan Ampel dan kawankawan berdakwah kepada Adipati Aria Damar dari Palembang. Berkat keramahan dan kebijaksanaan Raden Rahmat, akhirnya Raden Aria Damar sudi masuk Islam bersama isrinya, yang diikuti pula oleh hamper seluruh anak negerinya (Ali Murtopo, 1971:88).

Ketiga, adalah melakukan perang ideologi untuk memberantas etos dan nilainilai dogmatis ang bertentangan dengan aqidah Islam, di mana para ulama harus menciptakan mitos dan nilai-nilai tandingan baru yang sesuai dengan Islam. Salah satu tugas utama dari para ulama yang telah dikader oleh Raden Rahmat adalah menyebarkan ajaran Islam, sebagimana telah dijelaskan di atas, adalah dengan nilai tandingan bagi ajaran Yoga-Tantra yang berazaskan Ma-Lima. (Ridin Sofwan, dkk, 2000: 261)

Keempat, adalah melakukan pendekatan terhadap para tokoh yang dianggap mempunyai pengaruh di suatu tempat dan berusaha menghindari konflik. Salah satu azas dakwah yang dicanangkan oleh Walisongo adalah menghindari konflik-konflik dengan cara melakukan pendekatan kepada para tokoh setempat, diilhami oleh cara dakwah yang dilakukan oleh para Nabi Muhammad saw, apa yang pernah dirintis oleh para Rasulullah untuk memperkuat kedudukan Islam di tengah peradaban Jahiliyah dewasa itu, yang kenyataannya relevan juga untuk diterapkan di Jawa oleh para Wali, meski dengan taktik yang disesuaikan. (Ridin Sofwan, dkk, 2000: 262)

Kelima, berusaha mengguasai kebutuhan-kebutuhan pokok yang sangat dibutuhkan oleh masyarakat, baik kebutuhan yang bersifat materil maupun spiritual. Faktor kebutuhan pokok amat vital bagi masyarakat dewasa itu adalah menyangkut masalah air, baik air sebagai kebutuhan keluarga sehari-hari maupun sebagai irigasi pertanian. (Ridin Sofwan, dkk, 2000: 262)

b. Metode Dakwah Walisongo

Keberhasilan dakwah para Walisongo tentu juga tidak terlepas dari 
metode yang mereka aplikasikan dalam pelaksanaan di lapangan. Secara umum, dapat dikatakan bahwa metode dakwah para Walisongo tidak terlepas dari metode ini digunakn oleh mereka dalam tokohtokoh khusus seprti pemimpin, orang terpandang dan terkemuka dalam dalam masyarakat, seperti para bupati, adipati, raja-raja ataupun menghadapi para bangsaan lainnya. Dasar dari metode ini merujuk kepada Al-Qur'an surah an-Nahl (16): 125.

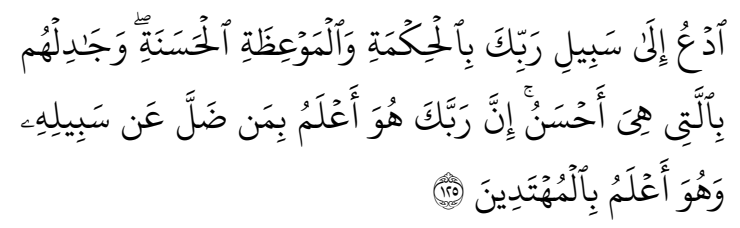

Artimya: Serulab (manusia) kepada jalan Tuban-mu dengan bikmah dan pelajaran yang baik dan bantablah mereka dengan cara yang baik. Sesunggubnya Tuhanmu Dialah yang lebih mengetabui tentang siapa yang tersesat dari jalan-Nya dan Dialah yang lebih mengetahui orang-orang yang mendapat petunjuk. (Q.S. an-Nabl, 125).

Rangkaian pengunaan metode diatas, kita dapati misalnya ketika Raden Rahmat da Sunan Ampel dan kawan-kawna berdakwah kepada Ariya Damar dari Pelembang. Berkat keramahan dan kebijaksanaan Reden Rahmat, Ariya damar kemudian sudi masuk Islam bersama istrinya, yang kemudian diikuti pula oleh hampir segenap rakyat dari anak negerinya. Begitu pula Sunan Kalijaga, didapati menggunakan metode dakwah tersebut diatas ketika mengajak Adipati pandanaran di Semarang. Pada mulanya terjadi perdebatan seru, tetapi perdebata itu berakhir dengan rasa tunduk sang Adipati
Masuk Islam. Bahkan karena cerita-cerita tradisional, sampai-sampai Adipati ini rela mengorbankan pangkat dan meninggalkan kemewahan dunia dan keluarganya demi untuk syarat-syarat yang diminta oleh Sunan Kalijag untuk diterima sebagai murid dalam berguru ilmu keislaman.

Metode al-hikmah sebagai sistem dan cara-cara berdakwah para wali merupakan jalan kebijaksanaan yang diselenggarakan secara popular, atraktif, dan sensational. Cara ini mereka pergunakan dalam menghadapi masyarakatv awam. Dengan tata cara yang amat bijaksana, masyarakat awam itu mereka hadapi secara massal. Kadangkadang terlihat sensasional bahkan ganjil dan unik sehingga menarik perhatian umum. Dalam rangkaian metode ini kita dapati misalnya, Sunan Kalijaga dengan gamelan Sekatennya. Atas usul Sunan kalijaga, maka dibuatlah keramaian dengan gamelan Sekatennya (dua kalimah pesaksian kunci keIslaman), yang diadakan di masjid agung dengan memukul gamelan yang sangat unik dalam hal langgaman lagu maupun komposisi instrumental yang telah lazim pada waktu itu. Keramaian diadakan menjelang peringatan hari mauled Nabi Muhammad saw. Selain itu, Sunan Kalijaga juga melarang lakon wayang baru dan menyelenggarakan pergelaran-pergelaran wayang.

Beberapa metode penting lainnya yang diterapkan oleh para walisongo sebagaimana dikemukakan oleh Ridin Sofwan dkk (2000: 271-284) yaitu, Pertama, metode pembentukan dan penanaman kader, serta penyebaran juru dakwah ke berbagai daerah. Tempat yang dituju ialah 
daerah- daerah yang sama sekali kosong dari penghuni atau kosong dari pengaruh Isdlam.

Kedua, dakwah melalui jalur keluarga/perkawinan. Sunan Ampel misalnya, putri beliau yang bernama Dewi Murthosiyah misalnya, dikawinkan dengan Raden Patah (Bupati Demak), Putri Sunan Ampel yang bernama 'Alawiyah' dikawinkan dengan Syarif Hidayatullah (Sunan Gunung Jati). Sedangkan Putri beliau yang bernama Siti Sariyah dikawinkan dengan Usman haji dar Ngudung.

Ketiga, mengembangkan pendidikan pesantren yang mula-mula dirintis oleh Syekh Maulana Malik Ibrahim adalah suatu model pendidikan Islam yang mengambil bentuk pendidikan biara dan asrama yang dipakai oleh pendeta dan biksu dalam mengajar dan belajar. Oleh sebab itu, pesantren di masa itu pengaruhnya masih terlihat sampai saat ini.

Keempat, dengan mengembangkan kebudayaan Jawa. Dalam kebudayaan Jawa Walisongo memberikan andil yang sangat besar. Bukan hanya pada pendidikan dan pengajaran, tetapi juga meluas pada bidangbidang hiburan, tata sibuk (perintang waktu luang), kesenian dan aspek-aspek lain dibidang kebudayaan pada umumnya.

Kelima, metode dakwah melalui sarana dan prasarana yang berkait dengan masalah perekonomian rakyat. Misalnya untuk efisiensi dalam perekonomian para wali berijtihad tentang kesempurnaan alatalat pertania, perabotan dapur, dan barang pecah belah. Dalaam pada itu, Sunan Kaslijaga menyumbangkan karya- karya yang berkenaan dengan pertanian seperti filsafat bajak dan cangkul. Dengan membuat jasa dalam bidang kemamuran rakyat melalui penyempurnaan sarana dan prasara menjadi lebih sempurna, beliau berharap dapat menarik perhatian dan ketaatan masyarakat agar menuruti ajakan Sunan Kalijaga serta wali-walinya.

Keenam, dalam mengembangkan dakwa Islamiyah di tanah Jawa para wali menggunakan sarana politik untuk mencapai tujuannya. Berangkat dari pemikiran ini, maka kehadiran keraton Demak tidak mungkin diabaikan begitu saja peranannya dalam sejarah penyebaran Isalam pada masa itu. Pentingnya kekuasan politik bagi kelangsungan dakwah ini tentunya didasari oleh para Walisongo, sehingga tidaklah mengherankan kalau mereka juga banyak terlibat dalam percaturan politik ini. Kebanyakan para wali adalah panglima perang, penasehat saja, atau juga penguasa itu sendiri. Pada saat Demak menyerang Majapahit, misalnya, yang menjadi penglima perang adalah Sunan Ngudung, yang kemudain digantikan oleh Sunan Kudus, dan dibantu oleh wali yang lain.

Dimanfaatkannya jalur kekuasaan dalam dakwah dapat dilihat juga pada proses pendirian masjid Demak. Masjid ini adalah masjid yang didirikan bersama oleh para wali sebagai pusat dakwah mereka. Namun tidak seperti pada umumnya, masjid ini tidak dikelola oleh seorang wali. Masjid Demak adalah masjid keraton yang pengelolaannya langsung dibawah penguasaan sultan bertahta dengan demikian, dapat dikatakan bahwa pusat dakwah walisanga tidak di tempat salah seorang wali atau pun masing -masing wali, 
tetapi di pusat kekuasaan politik di keraton. Selain itu, pada jaman Demak ini pula dikenal adanya semacam lembaga dakwah yang beranggotakan para wali dan dipimpin langsung oleh sultan.

\section{Penutup}

Berdasarkan uraian yang telah dikemukakan terdahulu, pada bagian penutup ini dapat diberikan kesimpulan antara:

1. Walisongo dipercaya sebagai peletak batu pertama Islam di pulau Jawa. Kiprah Walisongo dalam peta dakwah Islam di Indonesia pada umumnya, di pulau Jawa khususnya memang merupakan fakta sejarah yang tidak terebantahkan.

2. Kesuksesan dakwah Walisongo tidak terlepas dari peran srtategi dan metode yang mereka terapkan. Strategi tersebut yaitu Pertama, Pembagian Wilayah Dakwah. Para Walisongo dalam melakukan aktivitas dakwahnya antara lain sangat memperhitungkan wilayah strategis. Kedua, sistem dakwah dilakukan dengan pengenalan ajaran Islam melalui pendekatan persuasif yang berorientasi pada penaman aqidah Islam yan disesuaikan dengan situasi dan kondisi yang ada. Ketiga, adalah melakukan perang ideologi untuk memberantas etos dan nilai-nilai dogmatis ang bertentangan dengan aqidah Islam, di mana para ulama harus menciptakan mitos dan nilai-nilai tandingan baru yang sesuai dengan Islam. Keempat, adalah melakukan pendekatan terhadap para tokoh yang dianggap mempunyai pengaruh di suatu tempat dan berusaha menghindari konflik. Kelima, berusaha mengguasai kebutuhan-kebutuhan pokok yang sangat dibutuhkan oleh masyarakat, baik kebutuhan yang bersifat materil maupun spiritual.

Sedang metode yang mereka gunakan yaitu, Pertama, metode pembentukan dan penanaman kader, serta penyebaran juru dakwah ke berbagai daerah. Kedua, dakwah melalui jalur keluarga / perkawinan. Ketiga, mengembangkan pendidikan pesantren yang mula-mula dirintis oleh Syekh Maulana Malik Ibrahim adalah suatu model pendidikan Islamm yang mengambil bentuk pendidikan biara dan asrama yang dipakai oleh pendeta dan biksu dalam mengajar dan belajar. Keempat, dengan mengembangkan kebudayaan Jawa. Dalam kebudayaan Jawa Walisongo memberikan andil yang sangat besar. Kelima, metode dakwah melalui sarana dan prasarana yang berkait dengan masalah perekonomian rakyat. Keenam, dalam mengembangkan dakwa Islamiyah di tanah Jawa para wali menggunakan sarana politik untuk mencapai tujuannya.

3. Para Walisongo dalam melakukan aktivitas dakwahnya antara lain sangat memperhitungkan wilayah strategis. Beranjak dari sinilah, para Walisongo yang dikenal jumlahnya ada sembilan orang tersebut melakukan pemilihan wilayah dakwahnya, di Jawa Timur 5 wali, Jawa Tengah 3 wali, dan Jawa Barat 1 wali.

4. Walisongo ketika itu sangat bijak memanfaatkan seni yang telah berakar 
dan berkembang dalam masyarakat untuk menopang keberhasilan dakwah mereka. Di anatara seni yang popular dijadikan media dakwah oleh para Walisongo adalah wayang kulit dan lagu-lagu gending.

\section{DAFTAR PUSTAKA}

Ali Motofo, Strategi Kebudayaan. CSIC, Jakarta, 1971.

Arsyad, M. Natsir, Seputar Sejarah \& Muamalah, Al-Bayan, Bandung, 1993.

Burger, D.H., dan Prajudi Atmosudirjo, Sejarah Ekonomi dan Sosiologis Indonesia, Pradnya Paramita, Djakarta, 1970.

Effendy Zarkasi, Unsur Islam Dalam Pewayangan, Al- Ma’arif, Bandung, 1977.

Gatra, Edisi No.5 Tahun VIII, 22 Desember 2000.

Leur, J. C. Van, Indonesia Trade and Society, W. Van Hoeve Ltd., Bandung, 1955.

Ridin Sofwan, dkk. Islamisasi di jawa. Yogyakarta: Pustaka Pelajar, 2004.

Suryanegara, Ahmad Mansur, Menemukan Sejarah Wacana Pergerakan Islam di Indonesia, Mizan, Bandung, 1995.

Suryanegara, Ahmad Mansur, Menemukan Sejarab Wacana Pergerakan Islam di Indonesia, Mizan, Bandung, 1995.

Van Den Berg, H.J., Dari Panggung Sejarah, Terjemahan Koreskamp dan I.P. Simanjuntak, W. Van Hoeve Ltd., Bandung, 1959.

Yusuf A- Qardhawi, Islam \& Seni, Terjemahan Zuhairi Misrawi, Pustaka Hidayah, Bandung, 1996.

Jurnal "Al-Hiwar" Vol. 03, No. 05-Januari-Juni-2015 